\title{
Science and research in India
}

SIR - You say in your study of science in India that there is no dearth of funds. That is true. Organizations such as ICMR, CSIR, DST and UGC have enormous funds. But how much of this money goes to deserving people? Who, in any case, is deserving? In my opinion, those who deserve research funds are those who have worked in a specific area. Yet as things are, persons who have never seen tribes, never travelled in forest areas and have not worked on any aspect of anthropometry, haemoglobinopathies or population genetics may be allowed to spend 5 million rupees at the expense of investigators with relevant experience.

Last year, I asked a senior official of a major funding agency about this practice. His chilling answer was that "we do not wish even to look at projects costing less than three lacs"' $(300,000$ rupees). He further added that nothing can be done in science these days with one or two lacs of rupees. The truth is that there appears to be no remedy.

In India, there are few first-rate academic institutions when compared with the enormous number of students graduating every year. The general decline of students' interest in higher studies and the mushroom growth of colleges everywhere are unrecognized impediments to India's progress. The tolerance and even the cultivation of corrupt practices in the name of democracy is rampant in all universities and colleges, and in the publication of research work, as discussed in your report.

In my view, four out of five of our universities do not have enough money to support the basic necessities of modern science education, despite modest support from the University Grants Commission. The first reason is the apathy of state governments towards higher education, the second, the outlook of the bureaucrats who control events and, the third, the incompetence of the vice-chancellors. Nowhere in the world have vicechancellors such an uncertain future (they are replaced so often) and so little power. Even those with vision and ability can be quickly cowed by an under-secretary of the state government on any trivial matter. The exchange and extraction of mutual benefits is rife in the entire university education system. So I would modify Nature's slogan "Excellence in the midst of poverty" to "Excellence against all odds".

My twenty years of teaching experience lead me to conclude that most talent is distracted from research. Many faculty positions, research scholarships and senior fellowships are lying vacant and at least 60 per cent of research scholars leave research fellowships before completion. Nobody wants to acknowledge that part of the reason is the victory of incompetence over ability, mediocrity over genius. In my view, corrupt politicians and officials poison social progress only slowly, but corrupt teachers and particularly scientists can spoil generations. No nation should aim at nurturing mediocrity, whatever its national beliefs.

\section{Department of Genetics, \\ Bhopal University, Bhopal-462 026, India}

SIR - In my experience Indian scientists have the zeal and energy to succeed, but are handicapped by limited facilities and experience. The majority of institutes in India are sub-standard and producing graduates with limited practical knowledge, as boldly accepted by Dr Subramanian (Nature 307, 206; 1984). One reason for this is that institutes away from the centre suffer step-mother treatment. The centre and the University Grants Commission, the two main funding authorities, are too easily influenced by individuals heading the institutes governed by the centre, or by centrally located organizations who can approach the funding authority directly.

To obtain a research grant in India, one has to be not scientifically orientated, but politically motivated. The system brings non-scientifically minded individuals to the top who are against the return of their scientific compatriots from abroad, and cannot see their local colleagues rising quickly unless they share the credit for their work. Dr Balasubramanian (Nature 307, 321 ; 1984), sitting in one of the central institutes, has perhaps never had a chance to see establishments which lack the basic necessities to teach or initiate scientific research.

The main problem facing the plan to site an international centre in India (Nature 305,$350 ; 1983$ ) is that of supply of basic chemicals. Local products are not up to standard, and to import foreign goods, even after going through the red tape, one may have to pay 110 per cent customs duty on essential consumables of research. Sometimes it takes days to get supplies through customs.

Admittedly, India has its nuclear and space programmes to show the world but I do not agree with the claims of $\mathrm{Dr}$ Balasubramanian, who is perhaps unaware of the high prevalence of leprosy, tuberculosis and other communicable diseases in the very state where he is working. India must concentrate on educating society and research programmes should aim directly to reduce such human suffering. Many expatriate Indian scientists may wish to go back and the idea of a technology city is very rosy to them, but unless this city is controlled by a scientist with special powers to cut through the bureaucracy of Indian authorities, the city will be a failure. To raise the existing standards of Indian research, direct communication and collaboration with international scientists should be promoted.

S. S. PAPAIHA

Department of Human Genetics, University of Newcastle upon Tyne, Newcastle upon Tyne, UK

SIR - In your otherwise interesting survey, you were not able to give much time to the decaying but historical city of Calcutta, the first capital of British India, and the cradle of modern science in India. You rightly mentioned the late Sir J.C. Bose, the first Indian physicist FRS (1920) and his Bose Institute, founded in 1917 on the model of the Royal Institution of Great Britain. You also mentioned the late Professor S.N. Bose, FRS (of Bose-Einstein statistics) and his institute. But you omitted to mention a giant of Indian science, the late Professor M.N. Saha, FRS, a class-mate of the late S.N. Bose. It was after their joint English translation of Einstein's relativity papers in book form (published by Calcutta University) that Professor Bose was able to continue his work on his chosen subject while at Dacca University.

Professor Saha (the third Indian physicist FRS elected in 1927) made his impact on the world of astrophysics through his famous thermal ionization work in 1920, and became the first Khaira Professor of Physics, Calcutta University in 1921. After a spell at Allahabad University on his return to Calcutta in 1938 Professor Saha installed the first Indian cyclotron at what is now the Saha Institute of Nuclear Physics, inaugurated by the late Madame Joliot-Curie in 1951 with Saha as the founder-director. This institute also built the first electron microscope in India, and now has a thriving biophysics division.

In the premises of the Calcutta University Science College another great Indian scientist, the late Professor S.K. Mitra, FRS, established the Institute of Radio Physics and Electronics.

Third, at the Presidency College, Calcutta, the late Professor P.C. Mahalanobis built the nucleus of the Indian Statistical Institute. It was at Presidency College that the first cloud chamber for cosmic ray studies was constructed by Professor Rajen Sengupta, then a student of the late P.M.S. Blackett.

Finally, at Calcutta today the most active centre for scientific research is the Centre of Advanced Study on Cell and Chromosome Research, directed by Professor A.K. Sharma (in collaboration with his wife Mrs Archana Sharma), at the Department of Botany, Calcutta University. Professor Sharma's new technique for the study of the physical and chemical nature of chromosomes has been widely adopted all over the world.

Peico Electronics \& Electrical Ltd,

$P$-65 Taratolla Road,

Calcutta 700 088, India 